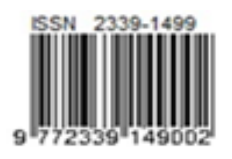

\title{
Integrasi E-Servqual, Model Kano, dan HOQ dalam Meningkatkan Kepuasan Pelanggan Jasa Ojek Online
}

\author{
Wilson Kosasih ${ }^{1, *}$, Iphov Kumala Sriwana ${ }^{2}$, Rico Adhesi ${ }^{1}$ \\ ${ }^{1}$ Program Studi Teknik Industri, Fakultas Teknik, Universitas Tarumanagara, Jakarta \\ ${ }^{2}$ Program Studi Teknik Industri, Fakultas Teknik, Universitas Esa Unggul, Jakarta \\ E-mail: wilsonk@ft.untar.ac.id ${ }^{*}$
}

\begin{abstract}
Online motorcycle taxi service providers become business opportunities that grow and develop. The development of digital business opportunities is also supported by the increasingly widespread service users. This research aims to determine the characteristics of online motorcycle taxi service users and the attributes that are priority for users. In this study, several methods are used and integrated include: e-ServQual, IPA (importance-performance analysis), Kano Model, and House of Quality. The measurement result of the consumer satisfaction index is $55.58 \%$, meaning that the consumers are quite satisfied with the online service. Based on the findings of this study, the attributes prioritized by consumers are the punctuality of the driver's arrival as stated in the application (attribute 14), the driver confirms the customer's order quickly (attribute 15), and the driver is easy to obtain (attribute 17). Finally, this study also recommends corrective actions to these service providers, among others: maintaining server reliability with a relative importance of $21.4 \%$, regularly conducting driver training with a relative importance of $15.2 \%$, and increasing the number of drivers with a relative importance $4.3 \%$.
\end{abstract}

Keywords: Consumer Satisfaction, e-ServQual, IPA, Kano Model, House of Quality

\begin{abstract}
Abstrak
Penyedia jasa ojek online menjadi peluang bisnis yang tumbuh dan berkembang. Berkembangnya peluang bisnis digital ini juga didukung dengan semakin maraknya pengguna jasa tersebut. Penelitian ini bertujuan untuk mengetahui karakteristik pengguna jasa ojek online dan atribut-atribut yang menjadi prioritas bagi pengguna. Dalam studi ini, beberapa metode digunakan dan diintegrasikan antara lain: eServQual, IPA (importance-performance analysis), Kano Model, dan House of Quality. Hasil pengukuran indeks kepuasan konsumen adalah $55,58 \%$, artinya pelanggan cukup puas terhadap jasa online tersebut. Berdasarkan temuan penelitian ini, atribut-atribut yang diprioritaskan oleh konsumen adalah ketepatan waktu datang driver sesuai yang tercantum di aplikasi (atribut 14), driver mengkonfirmasi order konsumen secara cepat (atribut 15), dan driver mudah untuk didapatkan (atribut 17). Terakhir, studi ini juga merekomendasikan tindakan-tindakan korektif kepada perusahaan penyedia jasa tersebut antara lain: menjaga kehandalan server dengan relative importance $21,4 \%$, melakukan training driver secara berkala dengan relative importance $15,2 \%$, dan Menambah jumlah driver dengan relative importance $4,3 \%$.
\end{abstract}

Kata kunci: Kepuasan Pelanggan, e-ServQual, IPA, Model Kano, House of Quality

\section{Pendahuluan}

Perkembangan teknologi telah memberikan peluang bagi masyarakat secara luas untuk meminimalisir risiko yang terjadi pada transportasi di Jakarta, baik dalam hal waktu, biaya, dan keamanan (Amajida, 2016).
Kemudahan akses aplikasi melalui ponsel pintar membuat beberapa perusahaan mengembangkan aplikasi transportasi berbasis teknologi, seperti jasa ojek online. Persaingan di bidang ini menuntut perusahaan penyedia jasa ini harus mengembangkan 
kualitas dan strategi layanan yang tepat agar terus mendapat kepercayaan dari konsumen. Oleh sebab itu, meningkatkan faktor-faktor layanan yang dianggap kritis oleh konsumennya perlu dilakukan secara berkesinambungan.

Penelitian yang dilakukan oleh Dwijoko \& Sterya (2017), menyatakan bahwa sikap driver terhadap pelanggan dapat mempengaruhi tingkat kepercayaan konsumen terhadap aplikasi transportasi berbasis teknologi tersebut. Kemudian penelitian oleh Ali et al. (2018) mempertegas hasil studi tersebut dan menambahkan 2 faktor lainnya, yaitu ketepatan waktu penjemputan, dan layanan komplain yang diberikan.

Kualitas jasa dapat didefinisikan sebagai tingkat ketidakcocokan antara ekspektasi atau keinginan konsumen dan persepsi konsumen (Zeithaml et al., 1993; Gasperz, 2012). Menurut Parasuraman et al. (1985, 1988), terdapat 10 dimensi yang kemudian dikelompokan dan disederhanakan ke dalam lima dimensi ServQual yang digunakan pelanggan untuk menilai kualitas jasa, antara lain: 1) keandalan, 2) daya tanggap, 3) jaminan, 4) empati, dan 5) bukti fisik. Dalam studi ini, kelima dimensi kualitas jasa ini yang dibahas lebih lanjut dan diadaptasikan dengan konsep bisnis jasa digital.

Berdasarkan latar belakang ini, penelitian ini bertujuan untuk menentukan atribut-atribut prioritas peningkatan kualitas jasa ojek online dan direkomendasikan tindakan perbaikan yang tepat guna meningkatkan kepuasan pengguna jasa tersebut. Penelitian ini difokuskan pada salah satu perusahaan penyedia jasa ojek online terbesar di Indonesia. Maka daripada itu, makalah ini membahas dan fokus mengenai peningkatan kualitas penyedia jasa ojek online menggunakan pendekatan integrasi eServQual, Model Kano, dan House of Quality.

\section{Metodologi}

\section{Pengumpulan Data}

Pertama-tama, kuesioner dirancang sedemikian rupa dengan atribut-atribut yang dapat digunakan untuk mengukur kelima dimensi kualitas jasa tersebut, seperti terlihat pada Tabel 1. Kuesioner penelitian ini menggunakan skala Likert 5 poin.

Responden kuesioner dipilih secara purposive sampling, dimana ditujukan kepada para pelanggan atau pengguna dari jasa ojek online yang berdomisili di DKI Jakarta. Adapun definisi kelima dimensi kualitas jasa yang digunakan untuk mengukur kepuasan pelanggan atau pengguna jasa ojek online, diadaptasikan dari e-TailQ (Wolfinbarger \& Gilly, 2003), adalah sebagai berikut: 1) Reliabilitas (reliability), berkaitan dengan kemampuan penyedia jasa online untuk memenuhi layanan yang dijanjikan secara akurat sejak pertama kali, termasuk berkenaan fungsionalitas teknis aplikasi bersangkutan dari penyedia jasa; 2) Daya tanggap (responsiveness), berkenaan dengan kesediaan dan kemampuan penyedia jasa online untuk membantu para pelanggan dan merespon permintaan mereka dengan segera; 3) Jaminan (assurance), berkenaan dengan pengetahuan dan kesopanan pekerja/mitra serta kemampuan penyedia jasa online dalam menumbuhkan kepercayaan (trust) dan privasi/keamanan pelanggan; 4) Empati (empathy), berkenaan dengan seberapa perusahaan memahami masalah para pelanggannya dan bertindak demi kepentingan pelanggan, serta memberikan perhatian personal kepada para pelanggan dan memiliki jam operasi yang nyaman; 5) Bukti fisik (tangibles), berkenaan dengan penampilan desain fisik fasilitas layanan, peralatan/perlengkapan, sumber daya manusia, dan materi komunikasi perusahaan, termasuk ketersediaan navigasi.

Pengembangan kuesioner juga diadaptasikan menggunakan pendekatan analisis Kano. Berdasarkan model tersebut, atribut-atribut layanan dapat dibedakan menjadi beberapa kategori, yaitu: 1) Must-be atau basic needs, pelanggan menjadi tidak puas apabila kinerja dari atribut yang bersangkutan rendah. Tetapi kepuasan pelanggan tidak akan meningkat jauh diatas netral meskipun kinerja dari atribut tersebut tinggi; 2) One dimensional atau performance needs, tingkat kepuasan berhubungan linear dengan kinerja atribut, sehingga pada kinerja atribut yang tinggi akan mengakibatkan tingginya kepuasan pelanggan pula; 3) Attractive atau excitement needs, tingkat kepuasan pelanggan akan meningkat sangat tinggi dengan meningkatnya kinerja atribut. Akan tetapi penurunan kinerja atribut tidak akan menyebabkan penurunan tingkat kepuasan; 4) Indifferent, pelanggan tida 
Tabel 1. Pengelompokan atribut-dimensi kualitas jasa ojek online

\begin{tabular}{|c|c|c|}
\hline Dimensi & Atribut & Pernyataan \\
\hline \multirow{7}{*}{$\begin{array}{l}\text { Tangible } \\
\text { (Berwujud) }\end{array}$} & Q1 & Driver menggunakan sepeda motor yang layak jalan dan tidak dimodifikasi \\
\hline & Q2 & Driver memberikan perlengkapan keamanan berkendara \\
\hline & Q3 & Driver menggunakan jaket identitas ojek online \\
\hline & Q4 & Driver berpakaian rapi dan bersepatu saat melakukan layanan \\
\hline & Q5 & Aplikasi ojek online memiliki tampilan yang menarik \\
\hline & Q6 & Aplikasi ojek online memiliki tampilan yang mudah dimengerti \\
\hline & Q7 & Aplikasi ojek online menyediakan navigasi dalam menggunakan aplikasinya \\
\hline \multirow{7}{*}{$\begin{array}{l}\text { Reliability } \\
\text { (Keandalan) }\end{array}$} & Q8 & Adanya pemberitahuan yang jelas apabila terjadi keterlambatan layanan \\
\hline & Q9 & Driver menaati tata tertib lalu lintas \\
\hline & Q10 & Driver menerapkan tarif sesuai dengan yang tertera pada aplikasi \\
\hline & Q11 & Layanan ojek online tersedia selama 24 jam \\
\hline & Q12 & Aplikasi ojek online memudahkan dalam pemesanan \\
\hline & Q13 & Kemudahan pembayaran yang tersedia di aplikasi ojek online \\
\hline & Q14 & Ketepatan waktu datang driver sesuai yang tercantum di aplikasi \\
\hline \multirow{5}{*}{$\begin{array}{l}\text { Responsiveness } \\
\text { (Daya tanggap) }\end{array}$} & Q15 & Driver mengkonfirmasi order konsumen secara cepat \\
\hline & Q16 & Aplikasi dapat diakses dengan mudah \\
\hline & Q17 & Driver mudah untuk didapatkan \\
\hline & Q18 & Layanan ojek online yang cepat dan tepat menanggapi keluhan \\
\hline & Q19 & Aplikasi ojek online menyediakan informasi yang up to date \\
\hline \multirow{6}{*}{$\begin{array}{r}\text { Assurance } \\
\text { (Jaminan) }\end{array}$} & Q20 & Driver trampil dalam mengemudikan motor \\
\hline & Q21 & Driver mempunyai pengetahuan dan info jalan yang akan dituju \\
\hline & Q22 & Driver dapat menjamin keselamatan konsumen \\
\hline & Q23 & Aplikasi ojek online memiliki layanan keluhan \\
\hline & Q24 & Aplikasi ojek online dapat memberikan keamanan dalam transaksi pembayaran online \\
\hline & Q25 & Privasi konsumen terlindungi \\
\hline \multirow{5}{*}{$\begin{array}{l}\text { Empathy } \\
\text { (Empati) }\end{array}$} & Q26 & Driver membantu mengangkat atau menaikan barang ke motor \\
\hline & Q27 & Driver membantu konsumen ketika menaiki motor \\
\hline & Q28 & Driver memberitahukan penggunaan perlengkapan berkendara yang benar \\
\hline & Q29 & Driver memberi sapa dan ucapan terima kasih kepada konsumen \\
\hline & Q30 & $\begin{array}{l}\text { Aplikasi ojek online memenuhi keingintahuan konsumen mengenai biaya perjalanan yang } \\
\text { akan diorder }\end{array}$ \\
\hline
\end{tabular}

peduli dengan adanya atribut yang ditawarkan sehingga ada atau tidaknya atribut tersebut tidak akan berpengaruh terhadap kenaikan atau penurunan tingkat kepuasan pelanggan. Dua kategori lainnya menunjukkan situasi berikut: ada kontradiksi dalam jawaban pelanggan terhadap pertanyaan, a.d.k.l. dipertanyakan; atau penilaian kami sebelumnya atas fungsional dan disfungsional adalah kebalikan dari apa yang dirasakan pelanggan, a.d.k.I. terbalik (CQM, 1993; Nofirza, 2011).

\section{Pengolahan Data}

Sebelum diolah lebih lanjut, instrumen penelitian diuji validitasnya (trial and error) dan uji reliabilitas-nya menggunakan teknik cronbach's alpha, artinya instrumen survei dinyatakan reliabel jika koefisien reliabilitas lebih besar dari 0,6 (Ahmad \& Kosasih, 2013). Jika ada atribut yang tidak reliabel maka atribut tersebut akan disortir atau dilakukan pertimbangan lainnya. Selanjutnya, dilakukan perhitungan consumer satisfaction index (CSI) yang merupakan suatu skala pengukuran yang menggambarkan tingkat kepuasan konsumen terhadap suatu produk atau jasa. Adapun tahap-tahapan dalam mengukur CSI adalah sebagai berikut (Rangkuti, 2003): 1) Menghitung weighted factor yaitu mengonversi nilai rata-rata tingkat kepentingan ke dalam angka persen, sehingga didapatkan total weighted factor $100 \%$; 2) Menghitung weighted score, yaitu nilai perkalian antara nilai rata-rata tingkat kinerja dengan weighted factor, 3) Menghitung weighted total, yaitu menjumlahkan weighted score dari semua atribut; 4) Menghitung satisfaction index, yaitu weighted total dibagi skala maksimal yang digunakan kemudian dikali $100 \%$.

Tingkat kepuasan responden secara menyeluruh dapat dilihat dari pencapaian CSInya. Merujuk pada Aditiawarman (2000), kriterianya dapat dikategorikan ke dalam 5 tingkatan yaitu: $0,00-0,34=$ tidak puas; 0,35 $-0,50=$ kurang puas; $0,51-0.65=$ cukup puas; $0,66-0,80=$ puas; $0,81-1,00=$ sangat puas. 
Tahap berikutnya, menentukan atribut mana yang menjadi prioritas menggunakan importance-performance analysis dan model Kano. Matriks importance-performance analysis (IPA), dikenal pula sebagai quadrant analysis, pertama kali diperkenalkan oleh Martilla \& James (1977) dan diaplikasikan dalam penelitian ini dengan tujuan untuk mengukur hubungan antara persepsi konsumen dan prioritas peningkatan kualitas produk/jasa (dikutip dari Tjiptono \& Chandra, 2007). Sedangkan, model Kano dikembangkan oleh Noriaki Kano (Kano et al., 1984). Dalam penelitian ini, Model Kano bertujuan untuk mengategorikan atribut-atribut dari produk maupun jasa berdasarkan seberapa baik produk tersebut mampu memuaskan kebutuhan pelanggan, seperti ditunjukkan pada Gambar 1.

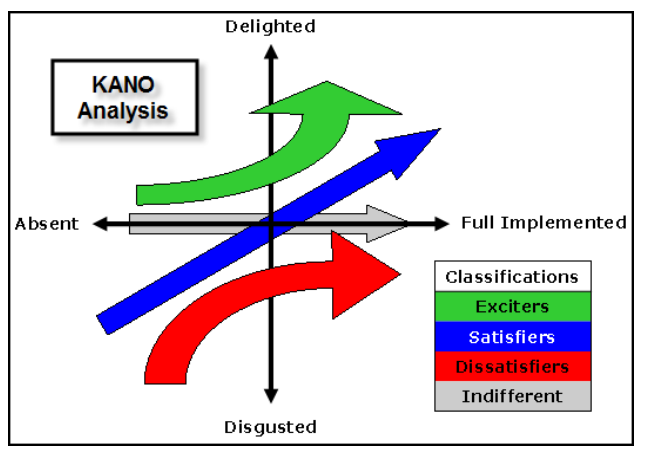

Gambar 1. Diagram analisis Kano

Tahap akhir, matriks house of quality (HOQ) digunakan untuk mengembangkan dan memperbaiki kualitas dari atribut-atribut penentu yang menjadi prioritas utama berdasarkan pertimbangan dari importanceperformance analysis dan model Kano. Matriks $\mathrm{HOQ}$ ini mendeskripsikan apa saja yang menjadi kebutuhan dan harapan pelanggan serta bagaimana memenuhinya, seperti dapat dilihat pada Gambar 2.

\section{Hasil dan Pembahasan}

Tabel 2 menunjukkan sebaran karakteristik demografi dari 250 responden, di mana data tersebut dinilai cukup mewakili karena domisili responden mencakup 5 kota madya di DKI Jakarta.

Hasil survei pertanyaan pendahuluan ditemukan bahwa mayoritas pelanggan (214 dari 250 responden) melakukan pembayaran secara tunai, seperti ditunjukkan pada Tabel 2 . Oleh sebab itu, dewasa ini banyak program diskon atau bundling untuk menarik minat pelanggan melakukan pembayaran elektronik atau non-tunai.

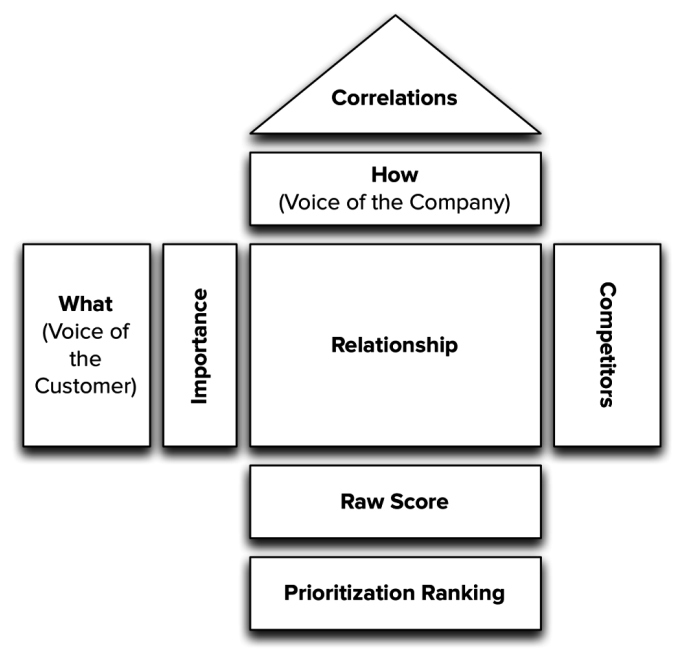

Gambar 2. The House of Quality (Cohen, 1995: 187)

Tabel 2. Karakteristik demografi dari responden ( $N$ $=250$ )

\begin{tabular}{|c|c|}
\hline \multicolumn{2}{|l|}{ Jenis Kelamin: } \\
\hline Laki- Laki & 145 \\
\hline Perempuan & 105 \\
\hline \multicolumn{2}{|l|}{ Umur Responden: } \\
\hline$<15$ tahun & 3 \\
\hline 15-25 tahun & 175 \\
\hline 26-35 tahun & 45 \\
\hline $35-44$ tahun & 18 \\
\hline$>44$ tahun & 9 \\
\hline \multicolumn{2}{|l|}{ Jenis Pekerjaan: } \\
\hline Pelajar/Mahasiswa & 148 \\
\hline Pegawai swasta & 60 \\
\hline Wiraswasta & 27 \\
\hline Pegawai negeri & 7 \\
\hline Lainnya & 8 \\
\hline \multicolumn{2}{|l|}{ Domisili: } \\
\hline Jakarta Barat & 62 \\
\hline Jakarta Timur & 53 \\
\hline Jakarta Utara & 41 \\
\hline Jakarta Selatan & 42 \\
\hline Jakarta Pusat & 52 \\
\hline \multicolumn{2}{|l|}{ Jenis Pembayaran: } \\
\hline Cash & 214 \\
\hline Kartu Debit / Credit / e-payment lainnya & 36 \\
\hline
\end{tabular}

Berdasarkan perhitungan CSI (lihat Tabel 3), didapatkan hasil akhir indeks kepuasan konsumen sebesar 55,58\%. Hal ini berarti konsumen cukup puas terhadap kinerja perusahaan penyedia jasa ojek online namun belum mencapai titik kepuasan optimal. 
Tabel 3. Hasil perhitungan CSI

\begin{tabular}{|c|c|c|c|c|c|}
\hline Atribut & $\begin{array}{c}\text { Nilai } \\
\text { Kinerja }\end{array}$ & N & MIS & $\begin{array}{c}\text { Weighted } \\
\text { Factor } \\
\text { (\%) }\end{array}$ & $\begin{array}{c}\text { Weighted } \\
\text { Score } \\
\text { (\%) }\end{array}$ \\
\hline Q1 & 552 & 250 & 2,21 & 3,31 & 7,36 \\
\hline Q2 & 591 & 250 & 2,36 & 3,54 & 7,88 \\
\hline Q3 & 550 & 250 & 2,20 & 3,30 & 7,33 \\
\hline Q4 & 536 & 250 & 2,14 & 3,21 & 7,15 \\
\hline Q5 & 559 & 250 & 2,24 & 3,35 & 7,45 \\
\hline Q6 & 586 & 250 & 2,34 & 3,51 & 7,81 \\
\hline Q7 & 570 & 250 & 2,28 & 3,42 & 7,60 \\
\hline Q8 & 566 & 250 & 2,26 & 3,39 & 7,55 \\
\hline Q9 & 568 & 250 & 2,27 & 3,41 & 7,57 \\
\hline Q10 & 581 & 250 & 2,32 & 3,48 & 7,75 \\
\hline Q11 & 548 & 250 & 2,19 & 3,29 & 7,31 \\
\hline Q12 & 558 & 250 & 2,23 & 3,35 & 7,44 \\
\hline Q13 & 577 & 250 & 2,31 & 3,46 & 7,69 \\
\hline Q14 & 528 & 250 & 2,11 & 3,17 & 7,04 \\
\hline Q15 & 552 & 250 & 2,21 & 3,31 & 7,36 \\
\hline Q16 & 577 & 250 & 2,31 & 3,46 & 7,69 \\
\hline Q17 & 552 & 250 & 2,21 & 3,31 & 7,36 \\
\hline Q18 & 538 & 250 & 2,15 & 3,23 & 7,17 \\
\hline Q19 & 550 & 250 & 2,20 & 3,30 & 7,33 \\
\hline Q20 & 583 & 250 & 2,33 & 3,50 & 7,77 \\
\hline Q21 & 546 & 250 & 2,18 & 3,27 & 7,28 \\
\hline Q22 & 546 & 250 & 2,18 & 3,27 & 7,28 \\
\hline Q23 & 526 & 250 & 2,10 & 3,15 & 7,01 \\
\hline Q24 & 571 & 250 & 2,28 & 3,42 & 7,61 \\
\hline Q25 & 560 & 250 & 2,24 & 3,36 & 7,47 \\
\hline Q26 & 525 & 250 & 2,10 & 3,15 & 7,00 \\
\hline Q27 & 508 & 250 & 2,03 & 3,05 & 6,77 \\
\hline Q28 & 555 & 250 & 2,22 & 3,33 & 7,40 \\
\hline Q29 & 549 & 250 & 2,20 & 3,29 & 7,32 \\
\hline Q30 & 567 & 250 & 2,27 & 3,40 & 7,56 \\
\hline & & Total & 66,70 & Total & 222,33 \\
\cline { 3 - 6 } & Rata- & 2,22 & Nilai & 55,58 \\
rata & & & \\
\hline & & & & & \\
\hline
\end{tabular}

Gambar 3 menunjukkan hasil pemetaan semua atribut Q1 s.d. Q30 berdasarkan nilai rata-rata kinerja, sebagai sumbu-x, dan nilai rata-rata kepentingan, sebagai sumbu-y. Hasil tersebut menemukan bahwa atribut yang masuk ke dalam: Kuadran I (attributes to improve) adalah atribut no. 14, 15, 17, 21, 22; Kuadran II (attributes to maintain) adalah atribut no. 2, 6, 8, 9, 10, 12, 20, 24, 25; Kuadran III (attributes to maintain) adalah atribut no. 1, 3, 4, 11, 19, 23, 26, 27, 29; dan Kuadran IV (attributes to de-emphasize) adalah atribut no. 5, 7, 13, 16, 28, 30.

Kemudian hasil rekapitulasi dari 250 responden yang dianalisis ke dalam kategori AOMIRQ pada setiap atribut (lihat Tabel 4) maka didapatkan yang masuk ke dalam kategori: A (attractive) adalah atribut no. 1, 7, 28; O (one dimensional) adalah atribut no. 2, $6,9,10,13,16,17,20,24,25,30$; । (indifferent) adalah atribut no. $3,4,5,8,11,12$, 14, 15, 18, 19, 21, 22, 23, 26, 27, 29.

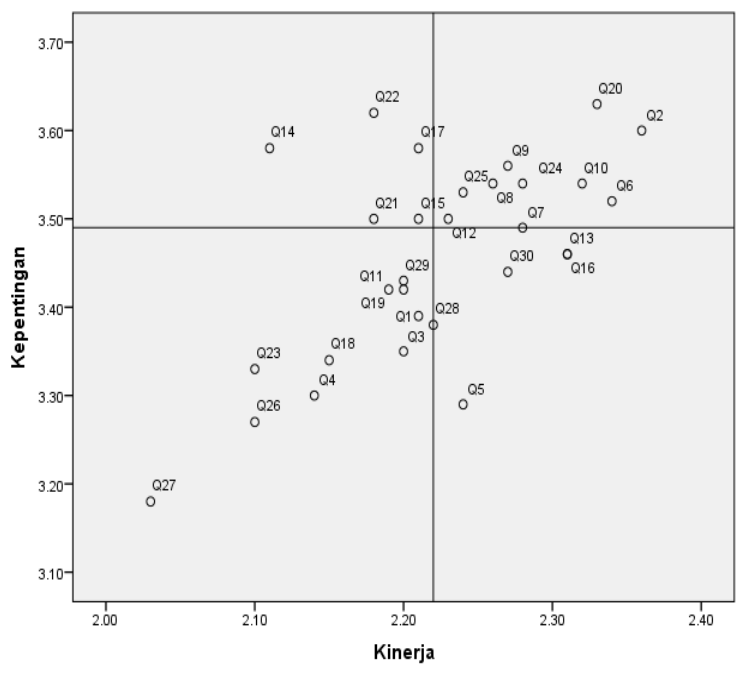

Gambar 3. Hasil matriks IPA jasa ojek online persepsi pelanggan di Jakarta

Selanjutnya atribut-atribut yang masuk ke dalam Kuadran I pada matriks IPA dan kategori $A$ \& O pada analisis Kano yang menjadi consumer's needs untuk dikembangkan lebih lanjut menggunakan matriks $\mathrm{HOQ}$, seperti terlihat pada Gambar 4.

Berdasarkan matriks $\mathrm{HOQ}$ yang telah dibuat didapatkan target layanan ojek online (studi kasus di Jakarta) diurutkan dari tingkat kepentingan relatif tertinggi hingga terendah adalah sebagai berikut: 1) Menjaga kehandalan server dengan relative importance $21,4 \%$; 2) Melakukan driver training secara berkala dengan relative importance $15,2 \%$; 3 ) Melakukan perbaikan tampilan secara berkala dengan relative importance $9,2 \%$; 4) Melakukan perbaikan aplikasi secara berkala dengan relative importance $6,3 \%$; 5) Menambah jumlah driver dengan relative importance $4,3 \%$; 6) Memberi sanksi tegas bagi driver yang melakukan kecurangan dengan relative importance $4,1 \%$; 6) Driver langsung menelepon atau mengirim pesan singkat konsumen dengan relative importance $4,0 \% ; 7)$ Menyediakan fitur GPS untuk aplikasi driver dengan relative importance $3,9 \% ; 8$ ) Aplikasi menyediakan estimasi biaya perjalanan yang akan dilakukan dengan relative importance $3,7 \%$; 9) Memberi sanksi tegas terhadap driver yang mengganggu privasi konsumen dengan relative importance $3,4 \%$. 
Tabel 4. Hasil kategori $A O M I R Q$ analisis Kano dari tiap atribut $(N=250)$

\begin{tabular}{|c|c|c|c|c|c|c|c|c|}
\hline Atribut & A & M & 0 & I & $\mathbf{Q}$ & $\mathbf{R}$ & $\mathbf{N}$ & Grade \\
\hline Q1 & 107 & 21 & 75 & 47 & 0 & 0 & 250 & $\mathbf{A}$ \\
\hline Q2 & 48 & 46 & 80 & 76 & 0 & 0 & 250 & 0 \\
\hline Q3 & 79 & 25 & 55 & 91 & 0 & 0 & 250 & I \\
\hline Q4 & 73 & 44 & 37 & 96 & 0 & 0 & 250 & I \\
\hline Q5 & 69 & 22 & 51 & 108 & 0 & 0 & 250 & I \\
\hline Q6 & 70 & 24 & 85 & 71 & 0 & 0 & 250 & 0 \\
\hline Q7 & 74 & 34 & 70 & 72 & 0 & 0 & 250 & A \\
\hline Q8 & 43 & 56 & 69 & 82 & 0 & 0 & 250 & I \\
\hline Q9 & 48 & 35 & 103 & 64 & 0 & 0 & 250 & 0 \\
\hline Q10 & 91 & 26 & 106 & 27 & 0 & 0 & 250 & 0 \\
\hline Q11 & 77 & 38 & 35 & 100 & 0 & 0 & 250 & I \\
\hline Q12 & 65 & 24 & 79 & 82 & 0 & 0 & 250 & I \\
\hline Q13 & 57 & 36 & 83 & 74 & 0 & 0 & 250 & 0 \\
\hline Q14 & 62 & 51 & 62 & 75 & 0 & 0 & 250 & I \\
\hline Q15 & 70 & 46 & 60 & 74 & 0 & 0 & 250 & $I$ \\
\hline Q16 & 68 & 29 & 85 & 68 & 0 & 0 & 250 & 0 \\
\hline Q17 & 68 & 28 & 79 & 75 & 0 & 0 & 250 & 0 \\
\hline Q18 & 55 & 34 & 76 & 85 & 0 & 0 & 250 & I \\
\hline Q19 & 69 & 42 & 50 & 89 & 0 & 0 & 250 & $\mathrm{I}$ \\
\hline Q20 & 71 & 21 & 97 & 61 & 0 & 0 & 250 & 0 \\
\hline Q21 & 71 & 39 & 52 & 88 & 0 & 0 & 250 & I \\
\hline Q22 & 54 & 32 & 81 & 83 & 0 & 0 & 250 & I \\
\hline Q23 & 54 & 40 & 60 & 96 & 0 & 0 & 250 & I \\
\hline Q24 & 55 & 36 & 87 & 72 & 0 & 0 & 250 & 0 \\
\hline Q25 & 54 & 42 & 89 & 65 & 0 & 0 & 250 & 0 \\
\hline Q26 & 91 & 25 & 38 & 96 & 0 & 0 & 250 & I \\
\hline Q27 & 66 & 28 & 23 & 133 & 0 & 0 & 250 & I \\
\hline Q28 & 80 & 30 & 61 & 79 & 0 & 0 & 250 & A \\
\hline Q29 & 66 & 33 & 66 & 85 & 0 & 0 & 250 & I \\
\hline Q30 & 71 & 30 & 81 & 68 & 0 & 0 & 250 & 0 \\
\hline
\end{tabular}

\section{Kesimpulan}

Hasil penelitian ini dapat disimpulkan bahwa berdasarkan pengolahan CSI, kepuasan pelanggan terhadap kinerja jasa ojek online di Jakarta tergolong cukup puas dengan nilai $55,58 \%$. Berdasarkan hasil matriks IPA, atribut-atribut yang menjadi prioritas utama untuk ditingkatkan oleh jasa layanan ojek online kendaraan beroda dua di Jakarta adalah atribut no. 14, 15, 17, 21, dan 22. Berdasarkan analisis metode Kano, atributatribut yang menjadi prioritas utama untuk ditingkatkan oleh jasa layanan ojek online di Jakarta adalah atribut no. 1, 7, dan 28.

Implikasi dari studi ini memberikan rekomendasi bagi perusahaan penyedia jasa ojek online untuk meningkatkan mutu layanannya secara terus-menerus. Penelitian ini menggunakan studi kasus DKI Jakarta, karena masyarakatnya heterogen dan dianggap dapat mewakili prilaku konsumen Indonesia pada umumnya. Penelitian ini tidak melakukan perhitungan acceptance sampling dalam penentuan ukuran sampel. Hal tersebut dapat menjadi pertimbangan pada penelitian selanjutnya sehingga sampel dianggap dapat lebih mewakili populasi yang diamati.

\section{Daftar Pustaka}

Aditiawarman, B. P. (2000). Pengukuran Tingkat Kepuasan dan Identifikasi Ketidakpuasan Pelayanan (Studi Kasus: Saving and Lending Unit Sucofindo). Skripsi yang tidak dipublikasikan. Bogor, ID: Departemen Matematika dan IImu Pengetahuan Alam, Institut Pertanian Bogor.

Ahmad \& Kosasih, W. (2013). Pengukuran Tingkat Kepuasan PelangganTerhadap Layanan di Bengkel XYZ dengan menggunakan Metode SERVQUAL, IPA, dan Kano. Paper presented at The $8^{\text {th }}$ SNMI (TI-36). Jakarta, ID: Jurusan Teknik Mesin, Fakultas Teknik, Universitas Tarumanagara. 


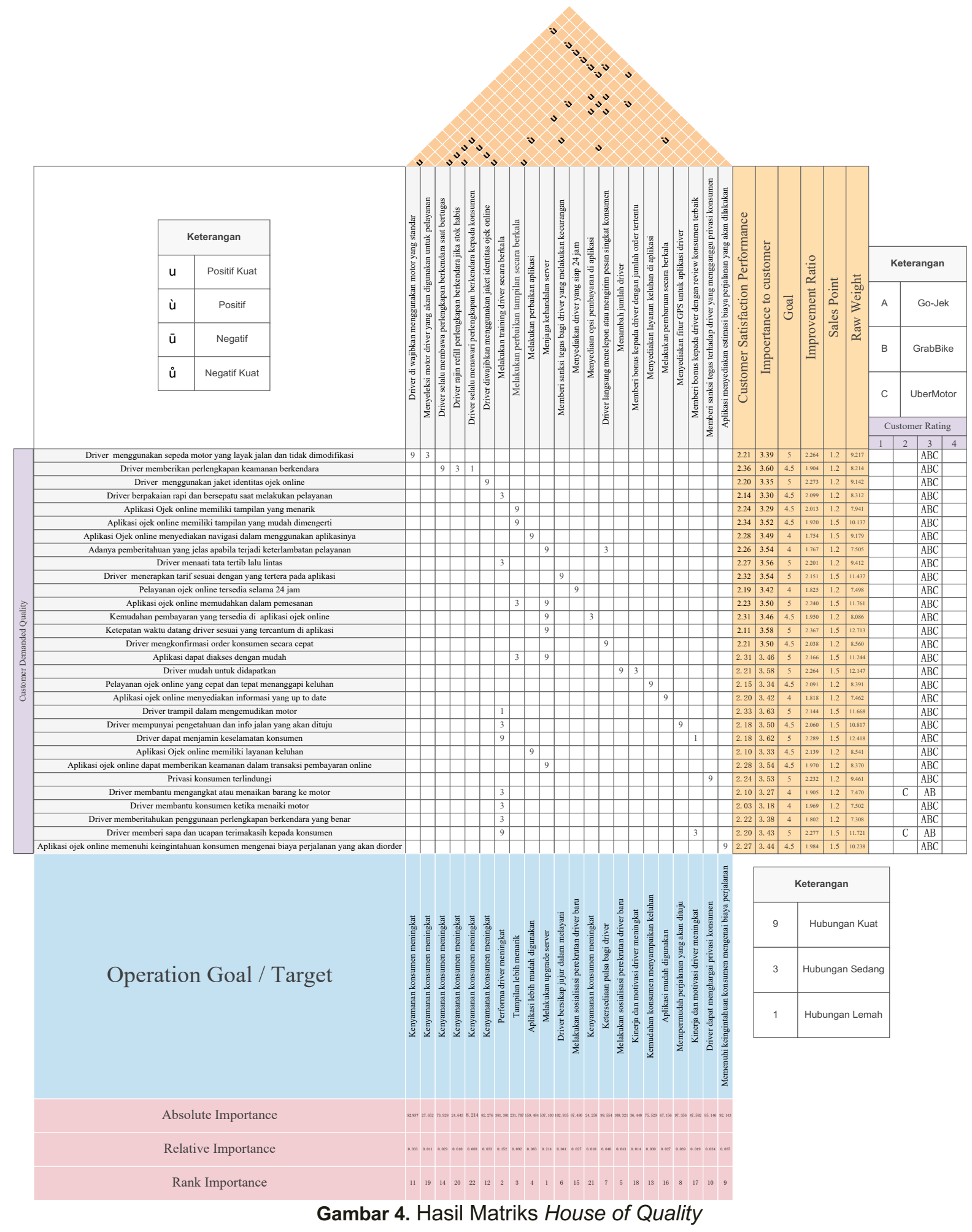

Ali, M., Kharis, A. \& Karlina, D. (2018). Faktorfaktor yang Menjadi Pertimbangan dalam Penggunaan Jasa Ojek Online (Go-Jek) di Kota Mataram. Jurnal IImu Administrasi Publik, 6(2), 75-84.

Amajida, F.D. (2016). Kreativitas Digital dalam Masyarakat Risiko Perkotaan: Studi Tentang Ojek Online "Go-Jek" di Jakarta.
INFORMASI Kajian IImu Komunikasi, 46 (1), 115-127.

Cohen, L. (1995). Quality Function Deployment: How to Make QFD Work for You. Reading Mass: Addison-Wesley.

CQM. (1993). A Special Issue on Kano's Methods for Understanding Customer 
Defined Quality. Center for Quality of Management Journal, 2(4), 3-36.

Dwijoko, A. \& Sterya, H. (2017). Motorcycles as Transport Service Based on Smart Phone Android Applications. Paper presented at The $6^{\text {th }}$ International Conference of Euro Asia Civil Engineering Forum. MATEC Web of Conferences 138, 07001.

DOI: 10.1051/matecconf/201713807001.

Gasperz, V. (2012). All-in-One®: Practical Management Excellence. Jakarta, ID: Vinchristo Publication.

Kano, N., Seraku, N., Takahashi, F., \& Tsuji, S. (1984). Attractive Quality and Must-be Quality. Journal of the Japanese Society for Quality Control, 14(2), 39-48.

Martilla, J.A. \& James, J.C. (1977). Importance-Performance Analysis. Journal of Marketing, 41, 77-79.

Nofirza, Kus Indrayani. (2011). Aplikasi Metode Kano dalam Analisis Indikator Kualitas Layanan di Rumah Sakit Arifin Ahmad Pekanbaru. Jurnal Sains, Teknologi dan Industri, 9(1), 1-8.

Parasuraman, A., Zeithaml, V.A., \& Berry, L.L. (1985). A Conceptual Model of Service
Quality and Its Implications for Future Research. Journal of Marketing, 49, 41-50.

Parasuraman, A., Zeithaml, V.A., \& Berry, L.L. (1988). SERVQUAL: A Multiple-Item Scale for Measuring Consumer Perceptions of Service Quality. Journal of Retailing, 64, 12-40.

Rangkuti, F. (2003). Measuring Customer Satisfaction. Jakarta, ID: PT. Gramedia Pustaka Utama.

Tjiptono, F. \& Chandra, G. (2007). Service, Quality, Satisfaction. Edisi kedua. Yogyakarta, ID: CV. Andi Offset.

Wolfinbarger, M. \& Gilly, M.C. (2003). eTailQ: Dimensionalizing, Measuring, and Predicting eTail Quality. Journal of Retailing, 79, 183-198.

Zeithaml, V.A, Berry, L.L., \& Parasuraman, A. (1993). The Nature and Determinants of Customer Expectations of Service. Journal of Academy of Marketing Science, 21(1), 1-12. 